\title{
POLA SEBARAN HUJAN DI DAS LARONA
}

\author{
Findy Renggono ${ }^{1}$
}

\begin{abstract}
Weather modification technology by means of cloud seeding is often done in the Larona watershed, in order to meet the water needs for electric power generation in the region. Information on the distribution pattern of rain clouds in the watershed is very important in determining the strategy of cloud seeding. Observations using the weather radar showed the distribution pattern of clouds in the region following the synoptic conditions. But during weak synoptic condition, local effect is also dominant as it has deep and wide lakes inside the watershed.
\end{abstract}

\section{Intisari}

Teknologi modifikasi cuaca dengan cara penyemaian awan sering dilakukan di DAS Larona, guna memenuhi kebutuhan air bagi pembangkit tenaga listrik di wilayah tersebut. Informasi mengenai pola distribusi awan hujan di dalam DAS sangat penting dalam menentukan strategi penyemaian awan. Pengamatan dengan menggunakan radar cuaca menunjukkan pola distribusi awan di wilayah tersebut mengikuti kondisi sinoptik. Akan tetapi pada saat sinoptik lemah, pengaruh local juga sangat dominant. Topografi yang berbukit-bukit dan tiga buah danau yang cukup luas dan dalam juga memberikan pengaruh yang besar pada pertumbuhan awan di dalam DAS.

Kata kunci : Awan hujan, radar

\section{PENDAHULUAN}

DAS Larona yang berada di Sulawesi Selatan, Indonesia merupakan wilayah yang hampir sebagian besar terdiri dari badan air, karena di dalamnya terdapat tiga buah danau. Air dari ketiga danau ini digunakan untuk menunjang PLTA yang terletak di output danau towuti. Ada tiga buah pembangkit yang dioperasikan oleh perusahaan tambang nikel di wilayah tersebut dengan total daya $400 \mathrm{MW}$.

Karena adanya siklus global yang menyebabkan pergeseran pola hujan, maka sering terjadi musim kering yang berkepanjangan yang menyebabkan kurangnya pasokan air untuk menggerakkan turbin pada plta. Untuk itu, kegiatan modifikasi cuaca dengan melakukan penyemaian awan kerap dilakukan di wilayah ini. Keberadaan awan merupakan syarat utama untuk dapat dilakukannya metode ini, maka dari itu dibutuhkan data dan kajian yang mendalam mengenai pola pertumbuhan dan karakteristik awan di wilayah ini agar strategi yang diterapkan dapat efektif dan efisien.

Radar cuaca merupakan salahsatu peralatan penting bagi kegiatan penyemaian awan. Dengan menggunakan radar, posisi dan kondisi awan

${ }^{1}$ Peneliti Madya - UPT Hujan Buatan, BPPT,

email: findy.renggono@bppt.go.id dapat dideteksi dengan cepat. Penggunaan radar untuk melakukan pengamatan awan di Indonesia sebelumnya banyak dilakukan di wilayah Sumatera. Mori (2006) menggunakan X-band radar untuk mengamati pertumbuhan awan di sepanjang pantai barat Sumatera. Nishi (2007) melakukan penelitian terhadap awan stratiform dengan VHF radar di Sumatera. Penelitian dengan VHF radar dapat pula digunakan untuk menentukan jenis

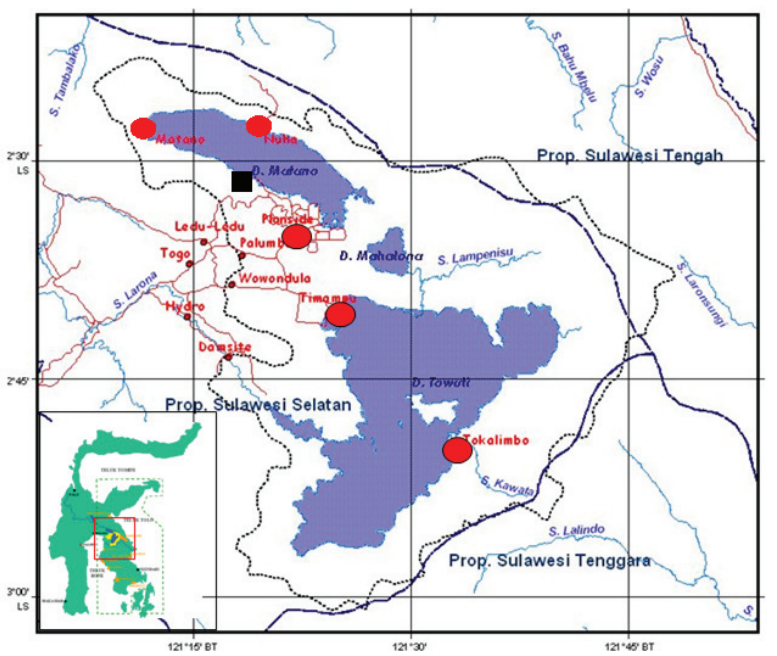

Gambar 1. Peta DAS Larona yang menunjukkan lokasi C-Band Radar (kotak hitam, dan AWS (lingkaran merah). Gambar insert adalah peta Sulawesi. 
awan (Renggono et.al., 2001). Pengamatan yang kontinyu menghasilkan pola harian dan bulanan dari kemunculan awan di Serpong, Jawa Barat.

Dengan menggunakan data reflektifitas C-band radar hasil pengamatan selama kegiatan hujan buatan di Sorowako, dilakukan kajian tentang pola kemunculan awan hujan di DAS Larona. Kajian ini hanya akan melihat sebaran awan hujan hasil pengamatan dengan radar pada saat kegiatan hujan buatan bulan Maret 2010. Penelitian ini juga didukung dengan data-data permukaan dari automatic weather station (AWS) yang dipasang dibeberapa tempat di dalam DAS dan data-data global lainnya, seperti synop dan TRMM.

\section{DATA DAN METODA}

Lokasi DAS Larona yang diapit oleh teluk Bone di sebelah Barat dan Laut Banda di sebelah timur membuat system pertumbuhan awan di wilayah ini sangat unik. Apalagi di dalam DAS juga terdapat tiga buah danau yang salah satunya termasuk danau yang terdalam di dunia. Ke tiga buah danau tersebut adalah Matano (166 km²), Mahalona $\left(24 \mathrm{~km}^{2}\right)$ dan Towuti $\left(562 \mathrm{~km}^{2}\right)$. Total luas DAS Larona adalah sekitar 2,477 km². Peta DAS Larona ditunjukkan pada gambar 1.

Radar cuaca yang digunakan dalam pada penelitian ini adalah C-band radar yang terletak di Sorowako $\left(2.53^{\circ} \mathrm{S}, 121.35^{\circ} \mathrm{E}\right)$, yang terletak ditepi barat danau Matano (lihat gambar 1). Radar yang sudah dipasang sejak tahun 2005 ini dimiliki oleh PT Valle Inco, namun dalam pengoperasiannya bekerjasama dengan UPT Hujan Buatan, BPPT. Radar ini hanya dioperasikan pada saat ada kegiatan penyemaian awan saja. Dalam tulisan ini data radar yang digunakan hanya data bulan Maret 2010.

Radar ini mempunyai daya jangkau sampai radius $100 \mathrm{~km}$ dengan kemampuan memetakan awan secara 3 dimensi dalam waktu setiap 6-8 menit. Data yang dapat diperoleh dari pengamatan dengan radar adalah nilai reflektifitas terhadap target. Dengan nilai ini dapat diketahui kondisi target sekaligus lokasinya terhadap radar. Semakin besar nilai reflektifitas, maka semakin pekat target yang terdeteksi. Jika awan hujan yang terdeteksi, maka semakin besar nilainya, awan hujan tersebut semakin banyak mengandung uap air. Dengan kerapatan waktu yang sampai 6-8 menit, pergerakan awan dapat dideteksi dengan cukup baik.

Data presipitasi dari TRMM 3B42RT yang diambil dari NOAA mempunyai cakupan wilayah pengamatan yang cukup luas. Namun karena pengamatannya dilakukan dari satelit yang bergerak mengelilingi bumi, maka kerapatan waktunya tidak sebaik pengamatan dengan radar yang dipasang tetap. Produk data presipitasi 3B42RT ini mempunyai kerapatan waktu 3 jam.

Data AWS yang digunakan pada penelitian ini adalah data hujan di Plantsite (2.57S, 121.38E), Matano (2.46S, 121.22E), Timampu (2.66S, 121.43E) dan Nuha (2.45S, 121.34E) (lihat tanda bulat pada gambar 1). Kerapatan waktu dari data hujan ini 30 menit dengan kemampuan menakar hujan sampai $0.25 \mathrm{~mm}$.

\section{VARIASI HUJAN DI DAS LARONA}

\subsection{Curah Hujan}

Pola variasi hujan di DAS Larona menurut Aldrian (2003), masih mirip dengan pola di Jawa, yaitu mempunyai satu puncak musim hujan dan musim kering. Hasil pengolahan data dari $\mathrm{GHCN}$ dengan metoda double correlation ini menghasilkan pola yang sama untuk sebagian Sulawesi bagian tengah sampai selatan. Pola seperti ini dipengaruhi oleh monsun, yaitu banyak hujan pada bulan Nopember sampai Maret, dan kering pada bulan April-Oktober.

Hasil pengamatan dengan menggunakan penakar hujan manual di plantsite sejak tahun 1977 menunjukkan hasil yang hampir sama (gambar 2). Pada gambar sebelah kiri ditunjukkan akumulasi curah hujan bulanan pada masing-masing tahun, dan gambar sebelah kanan merupakan rata-rata
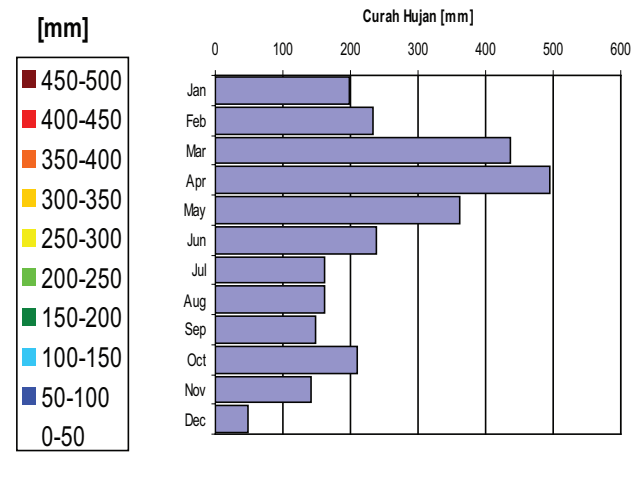

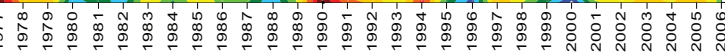

Gambar 2. Variasi curah hujan bulanan di Plantsite dari tahun 1977 - 2006 (gambar kiri) dan rata-rata akumulasi bulanannya (gambar kanan) 


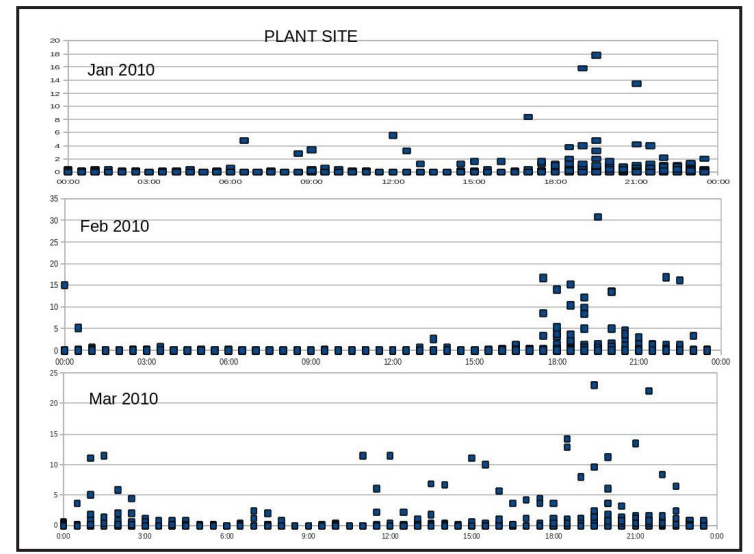

Gambar 3. Curah hujan berdasarkan waktu kejadian hujan di Plantsite untuk bulan Januari, Februari dan Maret 2010.

curah hujan bulanan selama 30 tahun. Terlihat pada gambar ini bahwa bulan yang banyak hujan adalah antara Januari sampai Juni, dengan puncak hujan terjadi pada bulan April. Bulan September-Desember merupakan bulan sedikit hujan, namun bulan Oktober agak sedikit basah karena ada tahun-tahun tertentu pada bulan ini yang mempunyai curah hujan agak tinggi, seperti misalnya pada tahun 1995-1996. Pada tahun El Nino seperti tahun 1981-1982 terlihat memiliki musim kering yang cukup panjang dan curah hujan pada musim hujan tahun 1997 tidak terlalu tinggi. Dengan variasi curah hujan seperti ini disimpulkan bahwa wilayah ini masih cukup dipengaruhi oleh ENSO.

Berdasarkan waktu kemunculannya, hujan di DAS Larona ini kebanyakan muncul setelah siang hari. Hasil pengukuran pada empat lokasi pengamatan dengan penakar otomatis menunjukkan hasil yang hampir sama. Gambar 3 merupakan curah hujan di plantsite berdasarkan waktu kejadian hujannya untuk bulan Januari-Maret 2010. Pada gambar ini terlihat bahwa hujan dengan curah hujan diatas $10 \mathrm{~mm} / \mathrm{jam}$ baru muncul setelah jam 17 sore untuk bulan Januari dan Februari, sedangkan pada bulan Maret muncul lebih awal, yaitu sekitar pukul 11.30.

Hasil yang sama juga terlihat di tiga stasiun lainnya, yaitu Matano (Gambar 4), Nuha (gambar 5) dan Timampu (gambar 6). Hujan di Matano sudah muncul sejak pukul 12 namun intensitasnya masih rendah, hujan dengan intensitas tinggi baru terlihat setelah pukul 17. Hasil yang sama juga terlihat di Timampu dan Nuha.

\subsection{Awan Hujan}

Darianalisisawanhujandengansyarattertentu (mempunyai reflektifitas lebih dari $20 \mathrm{dBZ}$ dan area minimal $4 \mathrm{~km} 2$ ), yang kemudian disebut sebagai

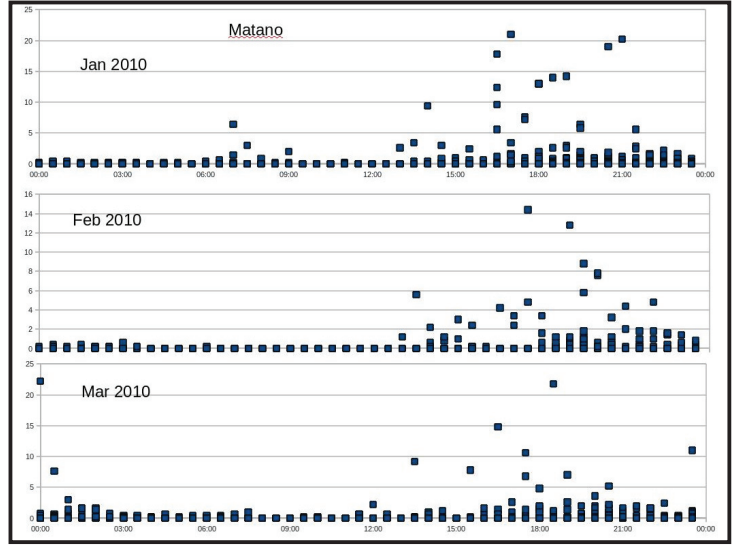

Gambar 4. Sama seperti gambar 3, tapi untuk stasiun Matano

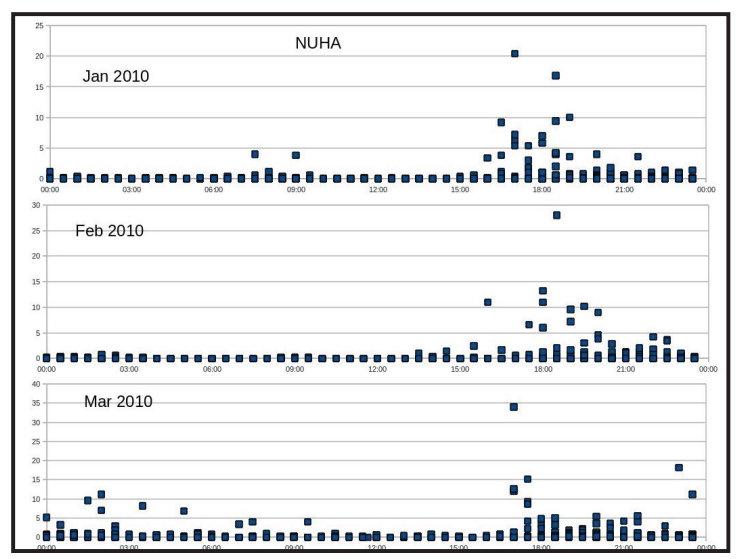

Gambar 5. Sama seperti gambar 3,tapi untuk stasiun Nuha

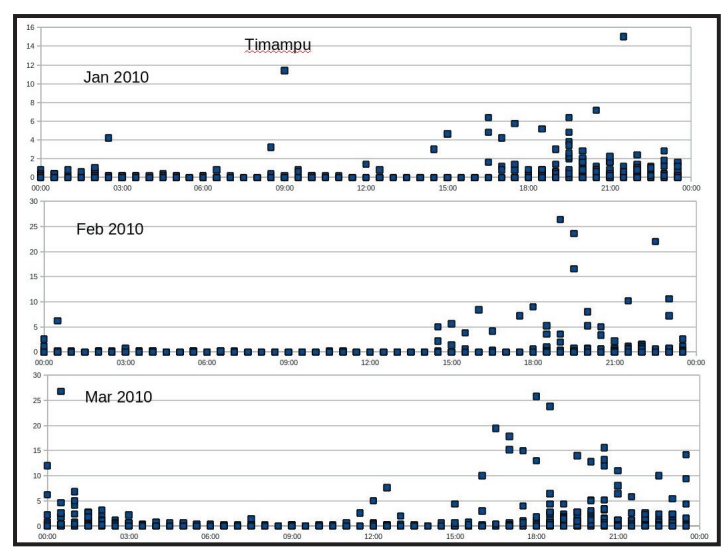

Gambar 6. Sama seperti gambar 3,tapi untuk stasiun Timampu

storm, diketahui bahwa storm banyak muncul setelah pukul 13 WITA dan puncak kemunculan awan hujan adalah bulan april (Renggono dkk, 2010). Kajian yang menggunakan data radar tahun 2006-2007 itu dilakukan berdasarkan jumlah storm yang muncul di dalam DAS. Kedua hasil ini juga sesuai dengan hasil pengamatan dengan penakar 

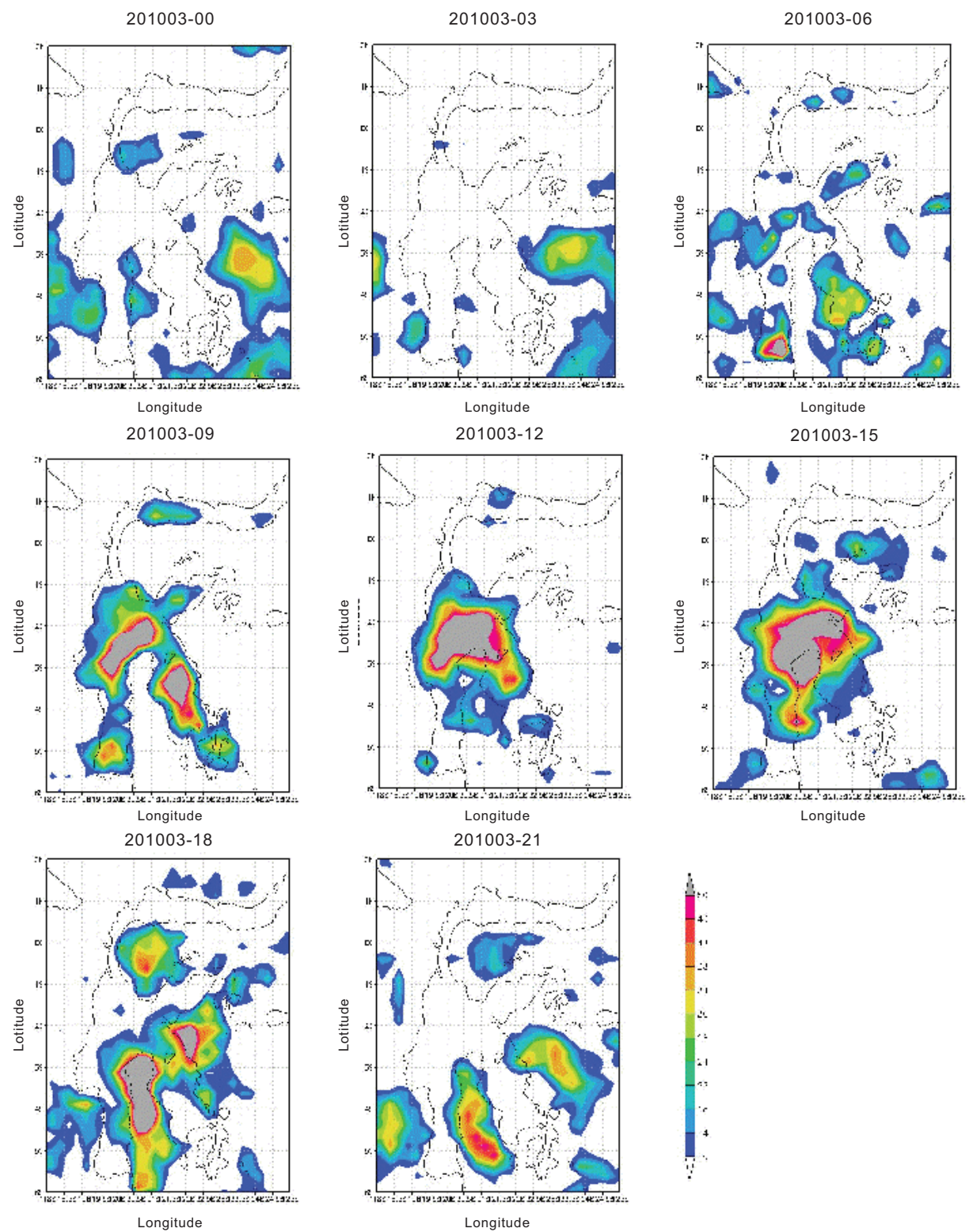

Gambar 7. Akumulasi presipitasi selama bulan Maret 2010 dari data TRMM untuk pukul 00-21Z.

hujan otomatis di plantsite seperti yang sudah dijelaskan di sub-bab 3.1.

Data dari satelit TRMM yang sudah dikonversi menjadi data presipitasi mempunyai kerapatan waktu 3 jam. Dari kajian data presipitasi TRMM selama bulan Maret 2010 menunjukkan pola variasi kemunculan awan hujan di wilayah Sulawesi. Gambar 7 adalah akumulasi curah hujan untuk bulan Maret 2010. Terlihat pada gambar ini data akumulasi nilai presipitasi untuk masingmasing pengamatan dari pukul $00 Z$ (pukul 08 WITA) sampai $21 Z$ (pukul 05 WITA). Pada pagi hari (pukul 21 dan 00Z) hujan hanya terlihat di atas laut saja, yaitu di teluk Bone, laut Banda dan selat Makasar. Setelah pukul $06 Z$ baru banyak terlihat hujan di daratan, terutama setelah pukul 09 sampai $18 Z$.

\section{CONTOH AWAN HUJAN DI TIMAMPU}

Hasil analisa dengan data curah hujan permukaan dan data satelit pada bab 3 menunjukkan bahwa kejadian hujan di DAS Larona dimulai pada siang hari. Untuk mengetahui struktur dan pergerakan awan, perlu dilakukan analisis dengan data radar. Pada bulan Maret, pengamatan awan dengan radar dilakukan setiap hari dari mulai pukul 10 pagi sampai 17 , sesuai dengan kegiatan penyemaian awan pada saat itu. Sebagai contoh kasus adalah kejadian hujan yang terjadi pada tanggal 10 Maret 2010 di Timampu.

Timampu yang terletak di tepi barat danau Towuti pada bulan Maret 2010 memiliki curah hujan 
yang lebih tinggi dibandingkan stasiun pengamat lainnya. Jumlah total curah hujan di Timampu selama bulan Maret terukur sebanyak $576.8 \mathrm{~mm}$. Sedangkan curah hujan untuk tanggal 10 Maret adalah $40.6 \mathrm{~mm}$.

\subsection{Kejadian Hujan}

Kemampuan radar dalam memantau pergerakan awan dengan kerapatan waktu hingga 6 menit dapat menggambarkan kondisi perawanan di DAS Larona secara lebih nyata. Dari hasil pengamatan pada tanggal 10 Maret 2010 diketahui bahwa pada hari itu awan-awan hujan sudah mulai tampak tumbuh di seputaran Sorowako dan di sebelah barat Timampu sejak pukul 10 pagi. Pergerakan awan terlihat dari barat ke timur, dan mulai berada di atas Timampu sekitar pukul 11.30.

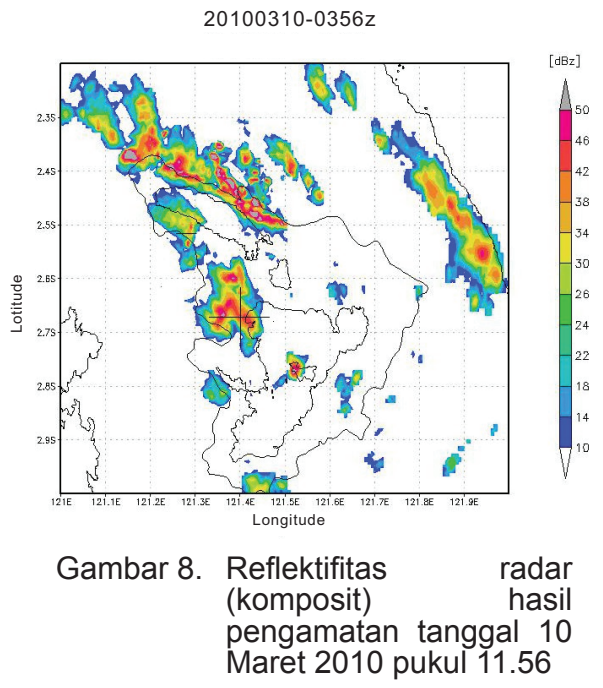

Di permukaan juga terpantau hujan dengan total curah hujan selama 2,5jam sebanyak $12.7 \mathrm{~mm}$.

Gambar 8 merupakan komposit dari reflektifitas radar pada pukul 11.56 WITA. Terlihat pada gambar ini bahwa Timampu (tanda silang) tertutup oleh awan dengan reflektifitas 30-40 dBZ. Gambar komposit ini hanya menampilkan nilai reflektifitas maksimum untuk setiap level ketinggian. Untuk mengetahui struktur awannya, perlu dilihat irisan tegak lurus dari reflektifitasnya. Reflektifitas yang tinggi di sepanjang sisi utara danau Towuti bukan merupakan reflektifitas dari awan hujan melainkan bukit yang cukup tinggi sehingga awan yang bergerak dari barat laut banyak berkumpul di tepi luar DAS terhalang oleh bukit ini.

Hubungan antara reflektifitas dengan curah hujan dapat dilihat pada gambar 9. gambar atas merupakan irisan tegak lurus waktu-ketinggian dari reflektifitas radar di Timampu, sedangkan gambar bawah merupakan jumlah curah hujan hasil pengukuran dengan penakar hujan otomatis. Terlihat jelas bahwa antara struktur vertikal dari reflektifitas radar dengan curah hujan di permukaan mempunyai korelasi yang baik. Semakin besar nilai reflektifitasnya semakin besar curah hujan permukaannya.

Nilai curah hujan permukaan (R) dapat diestimasi dengan menggunakan rumus $Z R$, yang mempunyai persamaan $Z=A R^{\wedge} b$. Nilai $A$ dan $b$ ini dapat berbeda-beda bergantung dari jenis, kondisi hujan dan lokasinya. Yang paling banyak digunakan adalah $A=200$ dan $b=1.6$, nilai ini didapat berdasarkan distribusi ukuran butir hujan MarshalPalmer. Hubungan Z-R tidak akan dibahas pada tulisan ini.

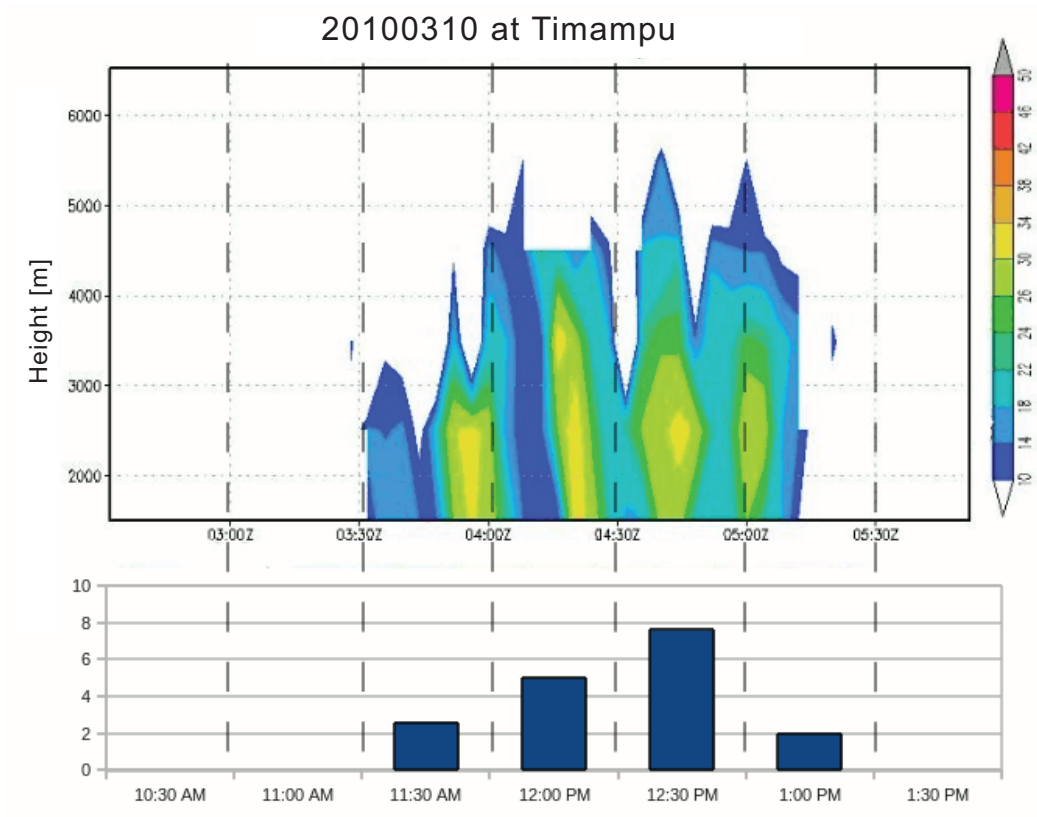

Gambar 9. Irisan tegak lurus waktu-ketinggian untuk reflektifitas radar di Timampu (atas), dan nilai curah hujan hasil pengukuran dengan AWS (bawah) 


\subsection{Pergerakan awan}

Analisis gradient wind yang diterbitkan oleh BOM (Buerau of Meteorology) Australia menunjukkan bahwa di sekitar DAS Larona angin berhembus dari Barat-Barat Laut. Kondisi ini menyebabkan awan yang bergerak dari arah Barat Laut bertumpuk di pebukitan di sisi Utara DAS (lihat gambar 8). Sedangkan di sisi barat DAS yang tidak terlalu tinggi bukitnya, awan dapat masuk dan tumbuh di dalam DAS.

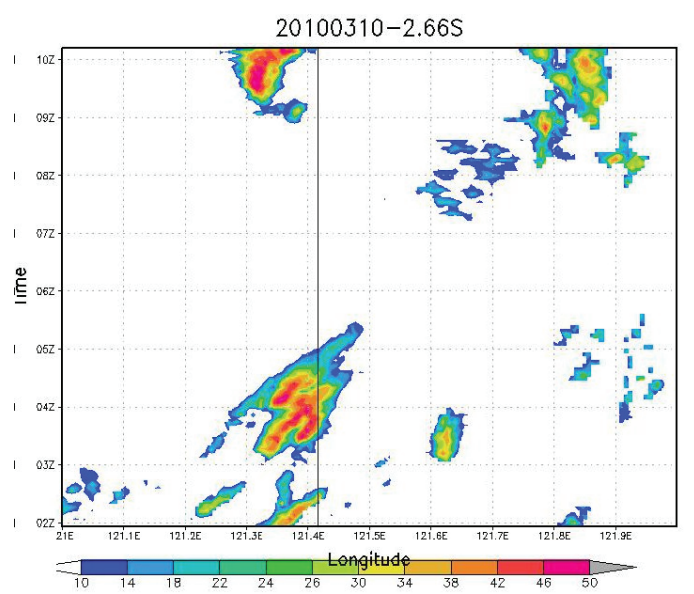

Gambar 10. Gambar Bujur-waktu pada lintang 2.66S. Garis tegak pada 121.43E adalah posisi Timampu.
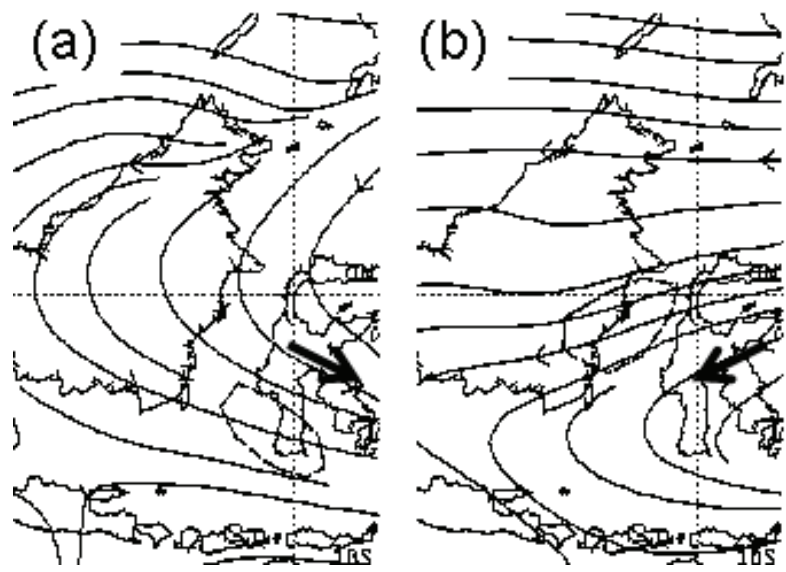

Gambar 11. Angin gradient tanggal (a) 3, (b) 7, (c) 14, dan (d) 27 Maret 2010 yang diambil dari BOM, Australia.

Pergerakan Barat-Timur awan di Timampu dapat dilihat pada gambar 10. Gambar ini adalah komposit untuk reflektifitas radar pada lintang 2.66 $6^{\circ} \mathrm{S}$. sumbu $X$ adala garis bujur dari $121.0^{\circ} \mathrm{E}$ sampai $122.0^{\circ} \mathrm{E}$ dan sumbu $\mathrm{Y}$ adalah waktu, dari $02 Z$ (10 WITA) sampai 10Z. Garis melintang $\left(121.43^{\circ} \mathrm{E}\right)$ menunjukkan lokasi Timampu. Terlihat pada gambar ini bahwa Timampu diselimuti awan hujan sekitar pukul 11.20-13.00 WITA. Pada pukul 11.00 WITA awan hujan tersebut berada di sebelah barat Timampu, dan bergarak ke arah timur sesuai dengan pertambahan waktu. Awan dengan
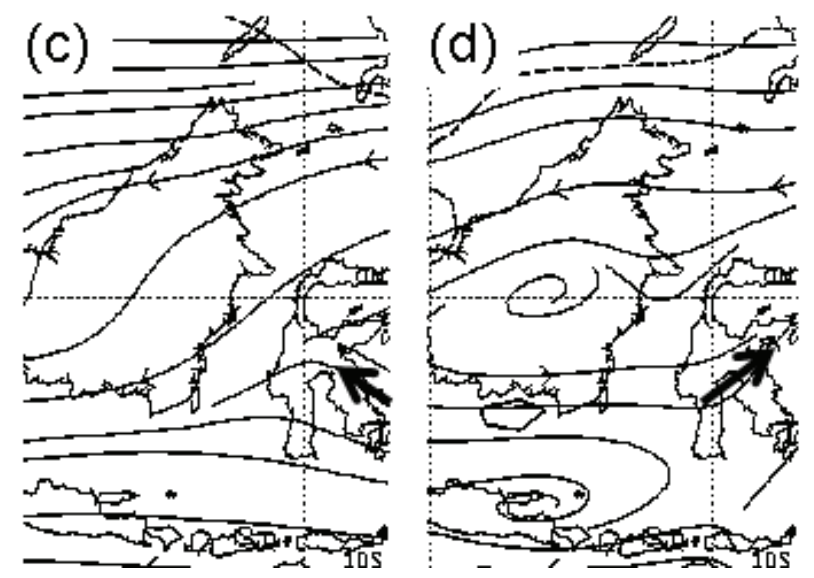

reflektifitas diatas $34 \mathrm{dBz}$ terlihat hanya sampai di Timampu, kemungkinan hujan deras hanya sampai di Timampu, sedangkan awan dgn reflektifitas kurang dari $30 \mathrm{dBz}$ hanyalah anvil nya saja yang masih bergerak sampai ke timur Timampu.

\section{DISKUSI}

Dalam skala sinop, angin di DAS Larona pada bulan Maret cukup bervariasi seperti yang terlihat pada gambar 11. Gambar ini adalah beberapa contoh analisa angin gradien untuk tanggal 3, 7, 14 dan 27 Maret 2010 yang dikeluarkan oleh BOM Australia. Kemunculan pusat tekanan rendah atau siklon tropis di samudra Pasifik bagian barat sangat mempengaruhi pola gradien angin di wilayah ini.

Gambar 12 adalah total akumulasi komposit harian dari reflektifitas radar selama bulan Maret. Reflektifitas yang tinggi tampak terlihat berada di luar DAS, yaitu di bagian utara dan timur. Awan yang berkumpul di bagian utara terjadi ketika angin bergerak dari barat laut-utara, yang lebih sering terjadi selama bulan Maret. Awan-awan ini kebanyakan tertahan oleh bukit-bukit yang berada di sisi utara DAS, tepat di sepanjang tepi utara danau Matano, tumbuh dan menjadi hujan. Bukit di sebelah utara danau Mahalona dan Towuti tidak terlalu rapat dan tinggi dibandingkan dengan yang

berada di utara danau Matano sehingga di daerah tersebut awan hujan dapat masuk ke dalam DAS.

Awan yang bergerak dari tenggara-timur akan tertahan oleh bukit-bukit di sisi timur DAS. Awan hujan yang tampak berada di dalam DAS berada di bagian barat danau Towuti. Awan hujan yang tumbuh di wilayah ini kebanyakan terjadi jika angin berhembus dari Barat. Kemungkinan faktor lokal juga banyak membantu dalam pertumbuhan awan di wilayah ini, seperti misalnya efek angin danau Towuti pada siang hari. Efek angin danau ini juga lah yang menyebabkan sedikitnya awan 


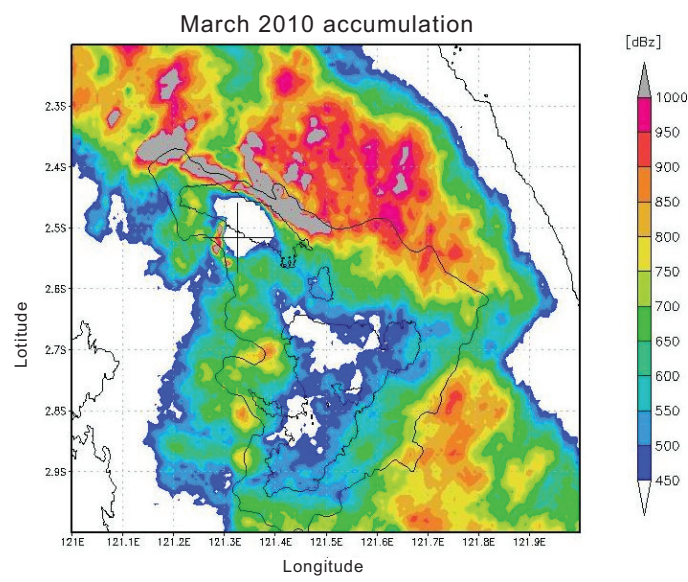

Gambar 12. Akumulasi reflektifitas radar untuk bulan Maret 2010 .

hujan yang berkumpul di atas danau. Pada gambar 12 yang merupakan data pengamatan radar untuk siang hari selama bulan Maret ini menunjukkan total reflektifitas awan diatas danau Matano dan Towuti lebih kecil dari $450 \mathrm{dBz}$.

\section{KESIMPULAN DAN SARAN}

DAS Larona mempunyai pola iklim yang unik karena lokasinya yang diapit oleh laut dan di dalamnya juga terdapat badan air yang cukup dalam dan luas. Pola hujannya secara umum mempunyai satu puncak musim hujan yaitu di bulan April dan terus menurun sampai bulan Desember, namun kadang-kadang terjadi curah hujan yang agak tinggi di bulan Oktober.

Angin dalam skala sinop banyak dipengaruhi oleh kemunculan pusat tekanan rendah di bagian utara Indonesia bagian timur. Pergerakan awan mengikuti kondisi sinop, jika angin gradien menunjukkan angin dari arah utara-barat laut, maka awan kebanyakan berkumpul di sisi utara batas DAS, sedangkan angin yang bertiup dari timurtenggara akan membuat awan banyak berkumpul di sisi timur DAS.

Pola sebaran awan hujan ini dapat digunakan sebagai estimasi curah hujan yang jatuh ke dalam DAS. Dengan melakukan kajian hubungan ZR, yaitu hubungan antara nilai reflektifitas radar dan curah hujan di permukaan, dapat diperkirakan sebaran hujan di wilayah tersebut. Nilai curah hujan yang diperoleh dapat pula menjadi masukan pada model-model hidrologi lain untuk mengetahui aliran permukaan, inflow atau menghitung hubungan depth-area-duration.
Pertumbuhan awan di dalam DAS selain dipengaruhi oleh kondisi sinoptik juga efek lokal sangat berpengaruh. Danau Towuti yang cukup luas dan danau Matano yang termasuk danau yang terdalam di dunia dapat memberikan efek angin danau yang cukup kuat pada siang hari pada saat sinoptik lemah. Untuk mengetahui seberapa besar pengaruh angin danau ini perlu pengkajian lebih lanjut dengan cara melakukan analis data radar dan juga analisis data angin permukaan.

\section{UCAPAN TERIMAKASIH}

Terimakasih sebesar-besarnya ditujukan kepada Andi Suntoro yang telah memberikan kesempatan kepada penulis untuk melakukan penelitian dengan menggunakan radar milik PT. Vale Inco. Ucapan terimakasih juga ditujukan kepada Kaimudin dari PT Vale Inco yang telah memberikan data-data AWS. Terimakasih kepada semua rekan-rekan di UPT Hujan Buatan yang telah bekerjasama melakukan pengamatan di Sorowako dengan baik. Pengamatan ini merupakan bagian dari proyek kegiatan penyemaian awan untuk mengurangi curah hujan di DAS larona yang dibiayai oleh UPT Hujan Buatan, BPPT atas permintaan dari PT Vale Inco.

\section{Daftar Pustaka}

Aldrian, Edvin and R. Dwi Susanto, Identification of Three dominant Rainfall Regions within Indonesia and Their Relationship to Sea Surface Temperature, Int. J. Climatol. 23: 1435-1452 (2003), DOI: 10.1002/joc.950

NCAR, Feasibility Study for the Augmentation of Rain in Sulawesi, Final Report, 2006

Nishi, Noriyuki, Masayuki K. Yamamoto, Toyoshi Shimomai, Atsushi Hamada, Shoichiro Fukao, 2007: Fine Structure of Vertical Motion in the Stratiform Precipitation Region Observed by a VHF Doppler Radar Installed in Sumatra, Indonesia. J. Appl. Meteor. Climatol., 46, 522-537.

Rinehart, R.E., 1991: RADAR for Meteorologists. Ronald E. Rinehart, Grand Forks, North Dakota. 334 pages. 
Renggono, Findy, H. Hashiguchi, S. Fukao, M. D. Yamanaka, S.-Y. Ogino, N. Okamoto, F. Murata, B. P. Sitorus, M. Kudsy, M. Kartasasmita, and G. Ibrahim, Precipitating clouds observed by $1.3-\mathrm{GHz}$ boundary layer radars in equatorial Indonesia, Annales Geophysicae (2001) 19: 889-897

Renggono, Findy, Erwin Mulayana, Djazim Syaifullah, Precipitating cloud observed by C-band radar at Sorowako, Indonesia, The Third International Workshop on Prevention and Mitigation of Meteorological Disasters in Southeast Asia, beppu, japan, 1-3 march 2010
Shuichi MORI, Jun-Ichi HAMADA, Manabu D. YAMANAKA, Yasu-Masa KODAMA, Masayuki KAWASHIMA, Toyoshi SHIMOMAI, Yoshiaki SHIBAGAKI, Hiroyuki HASHIGUCHI and Tien SRIBIMAWATI, 2006, Vertical Wind Characteristics in Precipitating Cloud Systems over West Sumatera, Indonesia, Observed with Equatorial Atmosphere Radar: Case Study of 23-24 April 2004 during the First CPEA Campaign Period, Journal of the Meteorological Society of Japan, Vol. 84A, pp. 113--131. 